\title{
EFFECTS OF SHADE ON GERMINATION TRAITS OF THE ENDANGERED cycad DioOn edule (Zamiaceae)
}

\author{
Laura Yáñez-Espinosa ${ }^{1,3}$ and Joel Flores ${ }^{2}$ \\ ${ }^{1}$ Instituto de Investigación de Zonas Desérticas, Programas Multidisciplinarios de Posgrado en Ciencias Ambientales, \\ Universidad Autónoma de San Luis Potosí \\ ${ }^{2}$ División de Ciencias Ambientales, Instituto Potosino de Investigación Científica y Tecnológica, A.C. \\ ${ }^{3}$ Corresponding author: lyaneze@uaslp.mx
}

\begin{abstract}
The endangered cycad Dioon edule requires shade provided by filtered sunlight under the canopy of trees or maternal plants during initial growth stages. It is known that germination improves under shade, but there is no report of radiation conditions. In order to understand how photosynthetic photon flux density (PPFD) affect germination traits, we evaluated some germination indexes. A sample of three mature strobili and 200 viable seeds per strobilus were selected to evaluate seed size (length, width, and fresh weight). Two experimental treatments were established simulating shade under the oak forest canopy with photosynthetic photon flux density $81 \mu \mathrm{mol} \mathrm{m}^{-2} \mathrm{~s}^{-1}$ (PPFD81), and under maternal plant canopy with photosynthetic photon flux density $17 \mu \mathrm{mol} \mathrm{m}^{-2} \mathrm{~s}^{-1}$ (PPFD17), as measured previously in the study site. Means of germination variables (germinability, germination rate, synchronization, mean germination time and relative frequency of germination) for the two treatments were compared using a $t$-test. Seed size and germination data were submitted to correlation analysis. A regression was performed to environmental predictors (temperature, relative humidity, photosynthetic photon flux density) of germinability. No significant correlation between seed size and germination traits was detected. Germinability was higher at PPFD17 (89\%) than PPFD81 (39\%), but mean germination time was similar across treatments. The germination rate was greater under PPFD17 but synchronization was the opposite. The low photosynthetic photon flux density stimulated $D$. edule germination, but also the spectral composition must be evaluated.
\end{abstract}

Key words: environmental predictors, germinability, gymnosperms, photosynthetic photon flux density, shade.

Resumen: La cícada en peligro de extinción Dioon edule requiere la sombra que le proporciona el dosel o las plantas maternas al filtrar la luz del sol durante su etapa inicial de crecimiento. Se sabe que la germinación es mejor con sombra, pero no existen reportes sobre las condiciones de la radiación. Evaluamos diferentes indicadores de germinación con el propósito de entender cómo es afectada por la densidad de flujo de fotones fotosintéticos (PPFD). Una muestra de tres estróbilos maduros y 200 semillas viables por estróbilo fueron seleccionadas para evaluar el tamaño de la semilla (largo, ancho y peso fresco). Dos tratamientos experimentales se establecieron simulando la sombra bajo el dosel del encinar con densidad de flujo de fotones fotosintéticos de $81 \mu \mathrm{mol} \mathrm{m}^{-2} \mathrm{~s}^{-1}$ (PPFD81) y bajo las plantas maternas con densidad de flujo de fotones fotosintéticos de17 $\mu \mathrm{mol} \mathrm{m}^{-2} \mathrm{~s}^{-1}$ (PPFD17), como se midió previamente en el sitio de estudio. La media de las variables (capacidad germinativa, velocidad de germinación, sincronización, tiempo medio de germinación y frecuencia relativa de germinación) para los dos tratamientos se compararon usando una prueba de $t$. Se aplicó un análisis de correlación a los datos de germinación y tamaño de semilla. Se aplicó una regresión a los predictores ambientales (temperatura, humedad relativa, densidad de flujo de fotones fotosintéticos) de la capacidad germinativa. No se detectó correlación significativa entre el tamaño de la semilla y las variables de germinación. La capacidad germinativa fue mayor en PPFD17 (89 \%) que PPFD81 (39\%), pero el tiempo medio de germinación fue similar. La velocidad de germinación fue mayor en PPFD17 pero menor en la sincronización. El bajo PPFD estimuló la germinación de D. edule, pero también la composición espectral debe ser evaluada.

Palabras clave: capacidad germinativa, densidad de flujo de fotones fotosintéticos, gimnospermas, predictores ambientales, sombra.

$\mathbf{T}$ he endangered cycad Dioon edule Lindl. (Zamiaceae) is a dioecious gymnosperm, whose adult female plants commonly produce only one strobilus over a time interval of 10-52 years (Vovides, 1990), and each strobilus bears 200 seeds on average (Vovides, 1990; Iglesias-Delfín and Alba-
Landa, 2004; Mora et al., 2013). In addition to the relatively limited seed production, the mortality at the seed stage is up to $90 \%$ under natural conditions (Vovides, 1990), attributed to pre-germination predation (Octavio-Aguilar et al., 2008; Mora et al., 2013) and dehydration (Vovides, 1990). Never- 
theless, the high capacity for germination of D. edule, which has up to 75-98\% viable seeds, compensates for the aforementioned disadvantages (Vovides, 1990; Iglesias-Delfín and Alba-Landa, 2004).

Each species has particular requirements for seed germination as a result of adaptations to the particular habitat where they occur (Chanyenga et al., 2012). Dioon species generally require shaded microsites during the initial growth stages, which are provided by filtered sunlight under the canopy of trees or maternal plants, and next to rocks (Álvarez-Yépiz et al., 2011; 2014). Seed dispersal of D. edule is limited, and mostly remain close to maternal plants after strobilus or cone ripening (Figure 1), which may be similar to Macrozamia miquelii (F.Muell.) A.DC. (Zamiaceae) seeds, of which $97 \%$ remained within $1 \mathrm{~m}$ of the maternal plants (Hall and Walter, 2013).

Several studies performed to test the germination response of cycads to availability of light and water (LópezGallego, 2013), or propagation conditions in nursery (Calonje et al., 2011; Iglesias-Delfín and Alba-Landa, 2004; López-Ovando and Treviño-Garza, 2008), reported that the germinability is better in shade or dark than in direct light under appropriate temperature and moisture in glasshouse conditions, although the light values of the treatments were not reported even when it is relevant to know the amount of light necessary to improve seed germination.

Below the canopy in tropical forests the amount and quality of the light transmitted is reduced, affecting seed

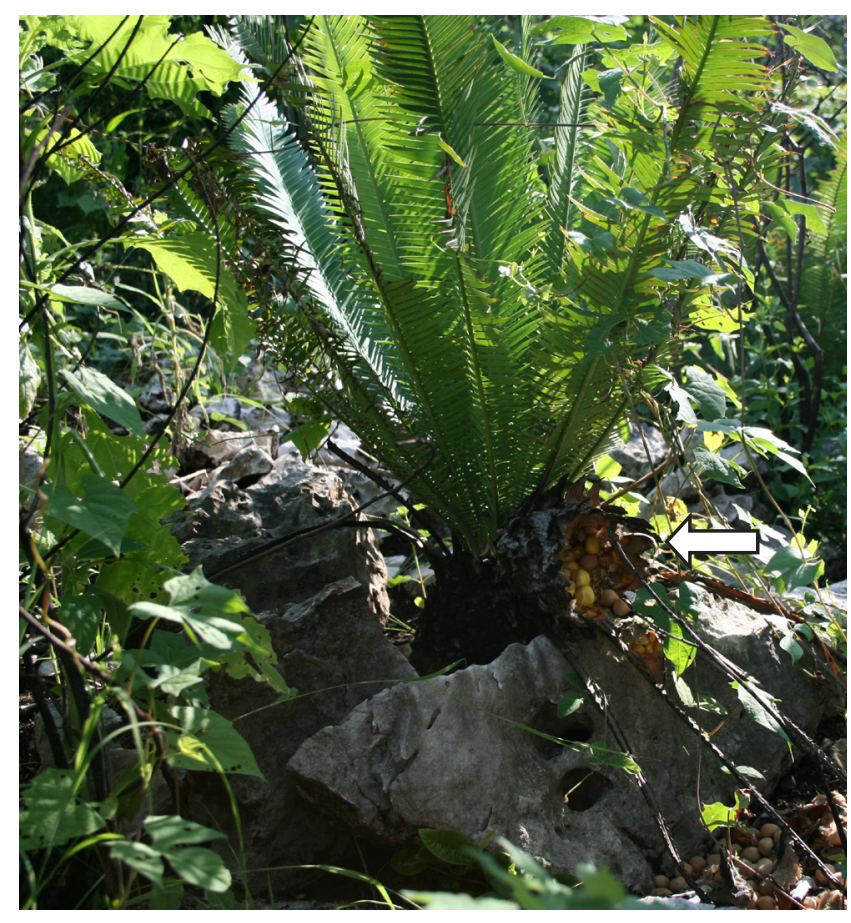

Figure 1. Dioon edule adult female plant with disintegrated cone in the base (arrow), and the seeds dispersed in the immediate vicinity of the maternal plant. germination (Vázquez-Yanes et al., 1990). In the shade the photosynthetic photon flux density (PPFD) ranges from 2$25 \mu \mathrm{mol} \mathrm{m}^{-2} \mathrm{~s}^{-1}$ compared to $330-1,640 \mu \mathrm{mol} \mathrm{m}^{-2} \mathrm{~s}^{-1}$ in full sun (Vázquez-Yanes et al., 1990; Leishman and Westoby, 1994). Then, what advantages would there be for germination under shade in the field? It is likely that shade not only improves seed germinability but also affects other germination traits like synchronization or germination rate, resulting in significant ecological consequences. The success of seed germination will be reflected in the population characteristics, affecting the distribution and abundance of the species.

Even when reduction of light quality (red/far-red ratio) also has an effect on seed germination (Vázquez-Yanes et $a l ., 1990)$, in the present study, we aimed to quantify (1) the effect of seed size and shade (amount of light) on germination traits (germinability, germination rate, synchronization index, mean germination time, and the relative frequency of germination), and (2) the effect of environmental variables on germinability.

\section{Materials and methods}

The harvest site is located in the southern region of the Sierra Madre Oriental in the state of San Luis Potosi, Mexico $\left(21^{\circ} 46^{\prime} \mathrm{N}, 99^{\circ} 31^{\prime} \mathrm{W}\right)$ at $1,167 \mathrm{~m}$ a.s.1. The mean temperature is $21.0^{\circ} \mathrm{C}$ and the total annual precipitation is $684 \mathrm{~mm}$, with a prolonged dry season (November-May). The Dioon edule population is distributed in the oak forest-submontane scrub ecotone, mainly associated with Quercus polymorpha Schltdl. \& Cham., Quercus laeta Liebm. (Fagaceae) and Flourensia laurifolia DC. (Asteraceae). The photosynthetic photon flux density (PPFD) measured at noon during spring under the oak forest canopy was $93.9 \pm 9.6 \mu \mathrm{mol} \mathrm{m}^{-2} \mathrm{~s}^{-1}$ and under the $D$. edule maternal plant canopy was $15.5 \pm 1.7$

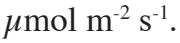

A sample of three mature strobili of Dioon edule was collected from three plants, and stored in dark at room temperature for 3 weeks. The seeds were extracted by removing the scales manually throughout the strobilus or cone axis, as explained in Mora et al. (2013). The seeds have three distinctive layers in the integument: the fleshy outer layer called the sarcotesta, the hard and stony middle layer called the sclerotesta, and the soft inner layer called the endotesta (Mora et al., 2013).The sarcotesta was removed, and the seeds were cleaned and stored in plastic bags at $9{ }^{\circ} \mathrm{C}$ for approximately one week before use.

A sample of 200 viable seeds per strobilus $(n=600)$ was selected, and each seed was numbered consecutively while recording size data to track germination. The length and width of each seed were measured with a digital Vernier calliper, and fresh weight was measured using an analytical balance with a precision of $0.0001 \mathrm{~g}$.

Four weeks after the cones were collected the seeds were 
soaked in water at room temperature for $12 \mathrm{~h}$ before sowing, as the seeds may have dehydrated during storage (Calonje et al., 2011). The seeds were placed laterally in plastic containers using a commercial germination mix (peat, perlite and limestone, 3:1:1), simulating natural conditions as how they would drop on the ground after they are released from the strobilus or cone (Calonje et al., 2011).

The experiment was conducted under glasshouse conditions in the facilities of the Research Institute of Desert Zones in the city of San Luis Potosi. We established one experimental treatment simulating soil surface conditions under the shade of the oak forest canopy exposed under polyethylene translucent cover with mean PPFD at noon of $81.2 \pm 0.5 \mu \mathrm{mol} \mathrm{m}{ }^{-2} \mathrm{~s}^{-1}$ (PPFD81), and other treatment simulating the shade under the maternal plant canopy exposed under a $60 \%$ black shade cloth with mean PPFD of $16.7 \pm 0.3 \mu \mathrm{mol} \mathrm{m}^{-2} \mathrm{~s}^{-1}$ (PPFD17).

Samples of 100 seeds from each strobilus were divided for each treatment ( $n=300$ per treatment) and placed randomly. The available soil moisture (mean $\pm \mathrm{SE}$ ) was maintained at $97.5 \% \pm 0.5 \%$ and was measured daily with a Digital Soil Moisture Tester (KS-D1, Delmhorst Institute, USA) used with gypsum sensor blocks (GB-1, Delmhorst Institute, USA) for each treatment from November 2008 to April 2009. Daily measurements of photosynthetic photon flux density (PPFD), air temperature (T) and relative humidity $(\mathrm{RH})$ were recorded with a data logger sensor (HOBO H08-004-02, Onset Computer Corporation, USA) in both treatments.

Germinated seeds were recorded every $10 \mathrm{~d}$ until the end of the experiment; any seed with at least $2 \mathrm{~mm}$ of radicle growth was considered to have germinated. Measurements were performed as follows: germinability (percentage of seeds in which the germination process reaches the end resulting in the embryo protrusion) was calculated with the equation:

$$
\mathrm{G}=\mathrm{n} \times 100 / s
$$

where $\mathrm{n}=$ number of normal seeds germinated, $s=$ total number of seeds; germination rate (velocity of germination, used to predict the relative vigor of samples), calculated using the equation (Maguire, 1962):

$$
G R=\sum_{i=1}^{k} n_{i} / t_{i}
$$

where, $n_{i}=$ number of normal seeds germinated in the time $i, t_{i}=$ number of days counted from the start of the experiment, $k=$ last day on which seeds germinated; synchronization index (degree of homogeneity of germination over time) was calculated by the equation (Ranal and Garcia de Santana, 2006):

$$
Z=\sum_{i=1}^{k} C_{n i, 2} / N
$$

being:

$$
\begin{gathered}
C_{n i, 2}=n_{i}\left(n_{i}-1\right) / 2 \\
N=\sum n_{i}\left(\sum n_{i}-1\right) / 2
\end{gathered}
$$

where $C_{n i, 2}=$ combination of the seeds germinated in the time $i$, two together, $n_{i}=$ number of normal seeds germinated in the time $i$; and mean germination time (average length of time required for maximum germination of a seed lot), calculated by the equation (Ranal and Garcia de Santana, 2006):

$$
M G T=\sum_{i=1}^{n} n_{i} t_{i} / \sum_{i=1}^{n} n_{i}
$$

where $n_{i}=$ number of normal seeds germinated in the time $i ; t_{i}=$ number of days counted since the day of sowing until the day of observation. The relative frequency of germination (behaviour of the seeds in the germination process over time) was calculated using the equation (Gogosz et al., 2010):

$$
\mathrm{f} i=n_{i} / \sum_{i=1}^{k} n_{i}
$$

where $n_{i}=$ number of normal seeds germinated in the time $i ; k=$ last day of observation.

The relative frequency of germination and germinability, previously transformed using the arcsine-square root function, and the germination rate, synchronization index and mean germination time were analysed. Germination variables were compared between the treatments using a $t$-test. Seed size and germination data were submitted to Pearson correlation analysis. A stepwise multiple regression was performed to select monthly environmental predictors ( $T, R H, P P F D)$ of germinability. All statistical analyses were performed with XLSTAT software (2013.5.02 v, Addinsoft, USA).

\section{Results}

The mean seed fresh mass, length and width did not differ significantly between treatments $(\mathrm{n}=600, \mathrm{df}=4, P>0.05)$ (Table 1). There was no significant correlation (PPFD81: $\mathrm{n}=116, P>0.05$; PPFD17: $\mathrm{n}=268, P>0.05)$, between the mean germination time and seed width, length or fresh mass, nor between seed germinability and width, length or fresh mass (Table 2).

Table 1. Dioon edule seed traits under two photosynthetic photon flux density treatments $\left(81\right.$ and $\left.17 \mu \mathrm{mol} \mathrm{m}^{-2} \mathrm{~s}^{-1}\right){ }^{*}=$ Significant differences $P<0.05$

\begin{tabular}{lcc}
\hline Seed traits & PPFD81 & PPFD17 \\
\hline Mean seed fresh mass $(\mathrm{g})$ & $4.24 \pm 0.02$ & $4.19 \pm 0.03$ \\
Length $(\mathrm{cm})$ & $2.34 \pm 0.02$ & $2.24 \pm 0.02$ \\
Width $(\mathrm{cm})$ & $1.80 \pm 0.02$ & $1.79 \pm 0.01$ \\
\hline
\end{tabular}


Table 2. Correlation between Dioon edule seed and germination traits. ${ }^{*}=$ Significant differences $P<0.05$

\begin{tabular}{|c|c|c|c|c|c|c|}
\hline & \multicolumn{2}{|c|}{ Seed width } & \multicolumn{2}{|c|}{ Seed length } & \multicolumn{2}{|c|}{ Fresh mass } \\
\hline & PPFD81 & PPFD17 & PPFD81 & PPFD17 & PPFD81 & PPFD17 \\
\hline Mean germination time & -0.113 & -0.246 & -0.211 & -0.138 & -0.138 & 0.019 \\
\hline Seed germinability & -0.437 & 0.376 & 0.409 & 0.322 & 0.628 & 0.356 \\
\hline
\end{tabular}

Dioon edule seed germinability was higher in the PPFD17 treatment (Table 3). The $t$-test showed that mean seed germinability differed significantly between treatments $(n=6$, $\mathrm{df}=4.0, P<0.05)$ from day 70 until the end of the experiment (Figure 2A).

The mean germination rate and the synchronization index also differed between treatments (Table 3$)(\mathrm{n}=6, \mathrm{df}=4.0$, $P<0.05$, for both), showing a higher germination rate and lower synchrony for the PPFD17 treatment, but the mean germination time ( $\mathrm{n}=6, \mathrm{df}=4.0, P>0.05)$ did not differ between treatments. Thus, the germination of seeds occurred over a long period in both treatments (more than 100 days), but in the PPFD17 treatment, more seeds germinated daily over a prolonged period, whereas PPFD81 seeds germinated 20 days later and ended 10 days earlier than those in the PPFD17 treatment.

Considering the relative frequency of germination, it is notable that $83.6 \pm 0.6 \%$ of PPFD81 and $66.4 \pm 0.5 \%$ of PPFD17 seeds germinated over $40 \mathrm{~d}$ between mid-February and March. Before March, only $16.7 \pm 0.1 \%$ of PPFD81 and $39.0 \pm 0.2 \%$ of PPFD17 seeds germinated, and during April, only $3.5 \pm 0.1 \%$ of PPFD81 and $12.3 \pm 1.0 \%$ of PPFD17 seeds germinated. The peak in germination that occurred in the PPFD81 treatment, at the end of March on the 140th day, differed significantly from the peak observed in the PPFD17 treatment $(\mathrm{n}=6, \mathrm{df}=4.0, P<0.05)$, and no other differences were observed (Figure $2 \mathrm{~B}$ ).

The multiple regression analysis $(\mathrm{n}=12, \mathrm{df}=2, \mathrm{~F}=22.5$, $P<0.0005)$ selected temperature $(B=0.017, \beta=1.248, P$ $<0.05)$ and PPFD $(B=-0.00005, \beta=-0.436, P<0.05)$ as the best predictors of germinability and discarded relative humidity $(P>0.05)$, indicating that a rise in mean monthly temperature and reduced photosynthetic photon flux density promoted seed germination $\left(R^{2}=0.849, \mathrm{CV}=49.1\right)$.

Table 3. Dioon edule seed germination traits under two photosynthetic photon flux density treatments $\left(81\right.$ and $\left.17 \mu \mathrm{mol} \mathrm{m}^{-2} \mathrm{~s}^{-1}\right){ }^{*}=$ Significant differences $P<0.05$

\begin{tabular}{lrr}
\hline Germination traits & \multicolumn{1}{c}{ PPFD81 } & \multicolumn{1}{c}{ PPFD17 } \\
\hline Germinability $(\%)$ & $38.7 \pm 9.93^{*}$ & $89.3 \pm 6.22$ \\
Germination rate $\left(\right.$ seeds $\left.\mathrm{d}^{-1}\right)$ & $1.40 \pm 0.27^{*}$ & $2.70 \pm 0.32$ \\
Synchronization index & $0.163 \pm 0.01^{*}$ & $0.102 \pm 0.01$ \\
Mean germination time $(\mathrm{d})$ & $118 \pm 4.04$ & $113 \pm 3.99$ \\
\hline
\end{tabular}

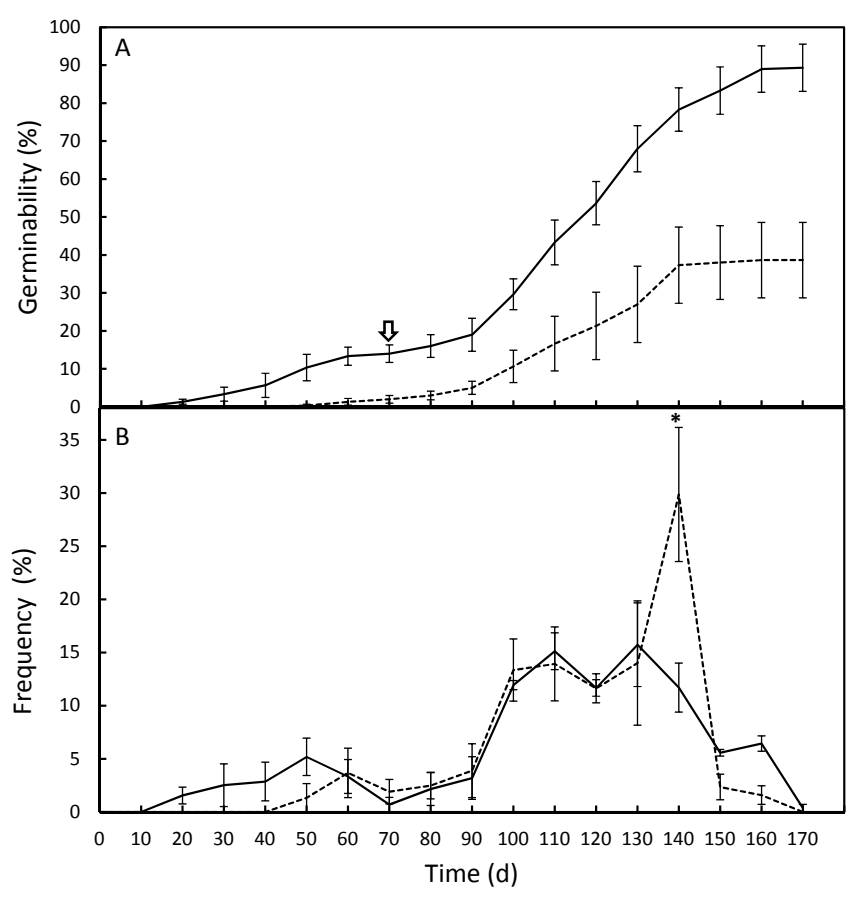

Figure 2. Photosynthetic photon flux density treatments (---PPFD81) and (-PPFD17) for Dioon edule seed germinability (A) and relative frequency of germination (B). The arrow indicates the beginning of significant differences between treatments $P<0.05$; * significant differences $P<0.05$.

\section{Discussion}

Germinability and germination time have been associated with seed size (Fenner and Thompson, 2005). However, in this study the seed size was not correlated with germination traits and shade affected all the seeds, as has been observed for Zamia fairchildiana L.D.Gómez (Lopez-Gallego, 2013) and other gymnosperms, such as Abies concolor (Gordon \& Glend.) Hildebr. and Taxus brevifolia Nutt. (Hewitt, 1998). It has been suggested that large-seeded species like cycads and other gymnosperms, survive under shade because enable seedlings to tolerate shade for longer in habitats where gaps in the canopy are regularly created (Leishman and Westoby, 1994).

This study confirmed that shade conditions improve $D i$ oon edule germinability (López-Ovando and Treviño-Garza, 2008). Seeds under PPFD17 treatment completed germination over a longer time period than seeds under PPFD81 treatment, although the latter showed a peak near the end of the period. Various studies have revealed that some cy- 
cads improve seed germination under low light or darkness, like Cycas revoluta Thunb., Dioon merolae De Luca, Sabato \& Vázq.Torres and Zamia fairchildiana L.D.Gómez, and most populations grow in shaded forests (Frett, 1987; López-Ovando and Treviño-Garza, 2008; Lázaro-Zermeño et al., 2012; Lopez-Gallego, 2013). The ability of seeds to germinate under both shade conditions indicates that $D$. edule seeds can germinate under the oak canopy or near the mother plant, forming a transient seed bank (seeds live in or on the soil for up to one year) (Walck et al., 2005; Octavio-Aguilar et al., 2009). High germination balances the limited seed production and its high mortality, and elevated seedling mortality may have more impact on population structure (Yáñez-Espinosa et al., 2014).

The mean germination time of Dioon edule is 30-60 days under controlled conditions, which represents the time it takes for the hypocotyls to push through the micropylar end of the seed (Thiessen, 1908; López-Ovando and TreviñoGarza, 2008). This time is expected because in large seeds the embryo requires longer to develop before it emerges, thus exhibiting a lower water absorption capacity (SánchezSalas et al., 2006).

In our experiment the mean germination time was extended by almost twice the time reported, and this could be attributed to a decrease in the temperature during January (below $20^{\circ} \mathrm{C}$ ). The optimum germination temperature of cycad seeds varies from $20{ }^{\circ} \mathrm{C}$ to $43{ }^{\circ} \mathrm{C}$ depending on the species (Calonje et al., 2011). The delay of germination when seeds are exposed to low temperatures also occurs in other gymnosperms, such as the tropical conifer Widdringtonia whytei Rendle, suggesting that this would reduce the risk of high seedling mortality during the dry season (January to May) (Chanyenga et al., 2012).

Successful germination may be determined by the inhibitory effect of elevated PPFD at the soil surface that has been demonstrated in many species (Fenner and Thompson, 2005), and our experiment suggests that lower PPFD performed with a non-selective neutrally coloured filter (polyethylene cover and black shade cloth) uniformly transmitting all wavelengths (McMahon et al., 1990) stimulated germination of Dioon edule. But sunlight transmitted through leaf canopy not only is reduced in quantity but also is altered in the spectral composition (Pons, 2000) and the low R/FR ratios will be evaluated in further experiments.

The ecological significance of photoinhibition of seed germination at the soil surface is not enough clear (Pons, 2000), but Dioon edule seedlings can recruit close of mother plant under shaded conditions, provided with a mechanism of shade tolerance, sufficient reserves to produce secondary compounds to defend against predators and energy to replace lost or damaged tissue (Leishman and Westoby, 1994), although intraspecific competition is high due to aggregation (Álvarez-Yépiz et al., 2014).

Our results are also significant for Dioon edule manage- ment, since the seed germination and plant development under shade before transplanting would do conservation more successful.

\section{Acknowledgements}

We thank Efraín Hernández, Raymundo Mora, and Gabriel Rubio their assistance in the field. Dioon edule cone collection was authorized by Mexican government (SEMARNAT SGPADGVS/00507/08). Funding was provided by The Cycad Society, Inc. (TCS 2007 Grants) to LYE for the research project "The chamal (Dioon edule Lindl.) in the state of San Luis Potosî". To the anonymous reviewers for their useful comments and suggestions.

\section{Literature cited}

Álvarez-Yépiz J.C., Dovčiak M. and Búrquez A. 2011. Persistence of a rare ancient cycad: effects of environment and demography. Biological Conservation 144:122-130.

Álvarez-Yépiz J.C., Búrquez A. and Dovčiak M. 2014. Ontogenetic shifts in plant-plant interactions in a rare cycad within angiosperm communities. Oecologia 175:725-735.

Calonje M., Kay J. and Griffith M.P. 2011. Propagation of cycad collections from seed: applied reproductive biology for conservation. Sibbaldia 9:77-96.

Chanyenga T.F., Geldenhuys C.J. and Sileshi G.W. 2012. Germination response and viability of an endangered tropical conifer Widdringtonia whytei seeds to temperature and light. South African Journal of Botany 81:25-28.

Fenner M. and Thompson K. 2005. The Ecology of Seeds. Cambridge University Press, Cambridge.

Frett J.J. 1987. Seed germination of Cycas revoluta. Journal of Environmental Horticulture 5:105-106.

Gogosz A.M., Bona C., Santos G.O. and Botosso P.C. 2010. Germination and initial growth of Campomanesia xanthocarpa $\mathrm{O}$. Berg. (Myrtaceae), in petroleum-contaminated soil and bioremediated soil. Brazilian Journal of Biology 70:977-986.

Hall J.A. and Walter G.H. 2013. Seed dispersal of the Australian cycad Macrozamia miquelii (Zamiaceae): are cycads megafauna-dispersed "grove forming" plants? American Journal of Botany 100:1127-1136.

Hewitt N. 1998. Seed size and shade-tolerance: a comparative analysis of North American temperate trees. Oecologia 114:432-440.

Iglesias-Delfín C.G. and Alba-Landa J. 2004. Variación de semillas de Dioon edule Lindl. (Zamiaceae) en el rancho El Niño, Veracruz, México. Foresta Veracruzana 6:15-20.

Lázaro-Zermeño J.M., González-Espinosa M., Mendoza A. and Martínez-Ramos M. 2012. Historia natural de Dioon merolae (Zamiaceae) en Chiapas, México. Botanical Sciences 90:73-87.

Leishman M.R. and Westoby M. 1994. The role of large seed size in shaded conditions: experimental evidence. Functional Ecology 8:205-2014.

Lopez-Gallego C. 2013. Genotype-by-environment interactions for seedling establishment across native and degraded-forest habitats in a long-lived cycad. The Botanical Review 79:542558. 
López-Ovando A. and Treviño-Garza E.J. 2008. Reproduction of chamal (Dioon edule Lindley) by seed. Ra Ximhai 4:45-55.

Maguire J.D. 1962. Speed of germination aid in selection and evaluation for seedling emergence and vigor. Crop Science 2:176-177.

McMahon M.J., Kelly J.W. and Decoteau D. R. 1990. Spectral transmittance of selected greenhouse construction and nursery shading material. Journal of Environmental Horticulture 8:118-121.

Mora R., Yáñez-Espinosa L., Flores J. and Nava-Zárate N. 2013. Strobilus and seed production of Dioon edule (Zamiaceae) in a population with low seedling density in San Luis Potosí, México. Tropical Conservation Science 6:268-282.

Octavio-Aguilar P., González-Astorga J. and Vovides A.P. 2008. Population dynamics of the Mexican cycad Dioon edule Lindl. (Zamiaceae): life history stages and management impact. Botanical Journal of the Linnean Society 157:381-391.

Octavio-Aguilar P., González-Astorga J. and Vovides A.P. 2009. Genetic diversity through life history of Dioon edule Lindley (Zamiaceae, Cycadales). Plant Biology 11:525-536.

Pons T.L. 2000. Seed responses to light. In: Fenner M. Ed. Seeds: The Ecology of Regeneration in Plant Communities, pp. 237260, CABI Publishing, Wallingford.

Ranal M.A. and Garcia de Santana D. 2006. How and why to mea- sure the germination process? Revista Brasileira de Botanica 29:1-11.

Sánchez-Salas J., Flores J. and Martínez-García E. 2006. Efecto del tamaño de semilla en la germinación de Astrophytum myriostigma Lemaire. (Cactaceae), especie amenazada de extinción. Interciencia 31:371-375.

Thiessen R. 1908. The vascular anatomy of the seedling of Dioon edule. Botanical Gazette 46:357-380.

Vázquez-Yanes C., Orozco-Segovia A., Rincón E., Sánchez-Coronado M.E., Huante P., Toledo J.R. and Barradas V.L. 1990. Light beneath the litter in a tropical forest: effect on seed germination. Ecology 71:1952-1958.

Vovides A.P. 1990. Spatial distribution, survival and fecundity of Dioon edule (Zamiaceae) in a tropical deciduous forest in Veracruz, Mexico, with notes on its habitat. American Journal of Botany 77:1532-1543.

Walck J.L., Baskin J.M., Baskin C.C., Hidayati S.N. 2005. Defining transient and persistent seed banks in species with pronounced seasonal dormancy and germination patterns. Seed Science Research 15:189-196.

Yáñez-Espinosa L., Flores J., Rodríguez-Millán P.S, Rubio-Méndez G. 2014. Influence of germination date on Dioon edule (Zamiaceae) seedling tolerance to water stress. Journal of Plant Research 127:413-422.

Received: September 28th, 2014

Accepted: December 12th, 2014 